\title{
Identification and Molecular Mapping of a Gene in Wheat Conferring Resistance to Mycosphaerella graminicola
}

\author{
Tika B. Adhikari, Joseph M. Anderson, and Stephen B. Goodwin
}

First and third authors: Crop Production and Pest Control Research, U.S. Department of Agriculture-Agricultural Research Service (USDAARS), Department of Botany and Plant Pathology; and second author: USDA-ARS, Department of Agronomy, Purdue University, 915 West State Street, West Lafayette, IN 47907.

Accepted for publication 14 April 2003.

\begin{abstract}
Adhikari, T. B., Anderson, J. M., and Goodwin, S. B. 2003. Identification and molecular mapping of a gene in wheat conferring resistance to Mycosphaerella graminicola. Phytopathology 93:1158-1164.

Septoria tritici leaf blotch (STB), caused by the ascomycete Mycosphaerella graminicola (anamorph Septoria tritici), is an economically important disease of wheat. Breeding for resistance to STB is the most effective means to control this disease and can be facilitated through the use of molecular markers. However, molecular markers linked to most genes for resistance to STB are not yet available. This study was conducted to test for resistance in the parents of a standard wheat mapping population and to map any resistance genes identified. The population consisted of $130 \mathrm{~F}_{10}$ recombinant-inbred lines (RILs) from a cross between the synthetic hexaploid wheat W7984 and cv. Opata 85. Genetic analysis
\end{abstract}

ABSTRACT

Bread wheat (Triticum aestivum L. em. Thell) is one of the most important world food crops. It is a hexaploid, having three closely related genomes (A, B, and D), each with seven chromosomes (17). The International Triticeae Mapping Initiative (ITMI) was established during the late 1980s with the main objective of mapping genetic markers such as restriction fragment length polymorphisms (RFLPs) and microsatellites or simple sequence repeats (SSRs) on the bread wheat genomes. For this purpose, the ITMI population W7984 $\times$ Opata 85 , consisting of $\approx 130$ recombinantinbred lines (RILs), is currently available (hereafter referred to as ITMI mapping population), of which between 70 and 114 RILs were considered for genetic mapping (33-35,39). A high-density genetic linkage map of wheat composed of RFLP $(3,27,33-35)$ and microsatellite (38-40) markers has been published recently. Most of these markers are inherited in a co-dominant manner and are chromosome specific $(38,39)$.

Septoria tritici leaf blotch (STB), caused by the ascomycete Mycosphaerella graminicola (anamorph Septoria tritici), is one of the most destructive foliar diseases of wheat in several temperate and subtropical regions of the world (10-12). In the United States, STB is widespread in the Pacific Northwest (8), the northern Great Plains (52), and the eastern soft-wheat region (43). Frequent rainfall and moderate temperatures favor disease development $(16,43$,

Corresponding author: S. B. Goodwin; E-mail address: sgoodwin@purdue.edu

Names are necessary to report factually on available data. However, the USDA neither guarantees nor warrants the standard of the product, and the use of the name implies no approval of the product to the exclusion of others that also may be suitable.

Publication no. P-2003-0626-01R

This article is in the public domain and not copyrightable. It may be freely reprinted with customary crediting of the source. The American Phytopathological Society, 2003. indicated that a single major gene controls resistance to $M$. graminicola in this population. This putative resistance gene is now designated Stb8 and was mapped with respect to amplified fragment length polymorphism (AFLP) and microsatellite markers. An AFLP marker, EcoRI-ACG/MseICAG5, was linked in repulsion with the resistance gene at a distance of approximately 5.3 centimorgans (cM). Two flanking microsatellite markers, $X g w m 146$ and $X g w m 577$, were linked to the Stb8 gene on the long arm of wheat chromosome $7 \mathrm{~B}$ at distances of 3.5 and $5.3 \mathrm{cM}$, respectively. The microsatellite markers identified in this study have potential for use in marker-assisted selection in breeding programs and for pyramiding of $\mathrm{S} t b 8$ with other genes for resistance to $M$. graminicola in wheat.

Additional keywords: genetic mapping, host-pathogen interaction, major gene, Triticum aestivum.

45), and yield losses ranging from 25 to $50 \%$ have been reported $(24,45)$. Resistant cultivars provide an effective, economical, and environmentally safe way to protect wheat from STB $(10,11)$.

Resistance to $M$. graminicola is simply inherited and may be controlled by one or two dominant or partially dominant genes $(4,6,28,41,42,46,49)$ or by two or three recessive genes $(42,50)$. At least seven genes conferring resistance to STB in wheat have been identified, named Stb1-Stb7 (4,6,46,50; R. A. McIntosh, personal communication). Only two of these genes appear to have been used extensively in breeding programs. Gene Stbl from the winter wheat cv. Bulgaria 88 was bred into the Indiana soft red winter cvs. Oasis and Sullivan $(36,37)$, and has maintained its effectiveness for more than 25 years $(\mathrm{H}$. Ohm, personal communication). The spring wheat cv. Tadinia contributed the single dominant resistance gene, $S t b 4$, to California wheat cultivars (46). This specific resistance remained effective for $\approx 15$ years $(46)$, but has deteriorated recently in the field; the Stb4-containing cv. Kern showed $\approx 25 \%$ infected leaf area in trials in Colusa County, CA, during the spring of 2000 (19). Likewise, the highly resistant cv. Gene (which also may contain Stb4) became highly susceptible within 5 years after its release in Oregon (9). With this rapid breakdown of resistance, there is a great need for incorporation of additional resistance genes into wheat cultivars intended for production in areas where STB is a threat.

Although phenotypic evaluation was very successful in breeding wheat for resistance to STB, it requires significant time and resources and depends on the environment for proper expression of resistance. An important goal of our research is to develop molecular markers for routine screening of experimental breeding lines for disease resistance. Molecular markers could be powerful tools for introgressing and pyramiding resistance to STB in wheat breeding through marker-assisted selection, because they can be detected at all plant growth stages and are not affected by the environment. Although several studies have been conducted using molecular 
markers to map a gene of interest in other wheat pathosystems, little information is available concerning the linkage relationships of genes for resistance to $M$. graminicola. The objectives of this study were to investigate the genetics of host-pathogen interactions between the ITMI mapping population and M. graminicola, identify amplified fragment length polymorphism (AFLP) and microsatellite markers closely linked to the gene for resistance to STB, and map its chromosomal location. Preliminary results of this study were presented previously (1).

\section{MATERIALS AND METHODS}

ITMI mapping population. In our greenhouse tests, the synthetic hexaploid wheat W7984 was highly resistant and Mexican cv. Opata 85 was highly susceptible to several isolates of $M$. graminicola (S. B. Goodwin, X. Hu, and F. I. Urmeev, unpublished data). We evaluated $130 \mathrm{~F}_{10}$ RILs developed by single-seed descent from the cross W7984 $\times$ Opata 85 for STB resistance. Seed of the mapping population were provided by P. McGuire (Genetic Resources Conservation Program, University of California, Davis).

Greenhouse conditions. The $130 \mathrm{~F}_{10}$ RILs were assessed for resistance to $M$. graminicola in a greenhouse of the Department of Botany and Plant Pathology, Purdue University, West Lafayette, IN during the spring seasons of 1998 to 2001. Wheat seed planted in metal flats were vernalized for 7 days at $4^{\circ} \mathrm{C}$, then transplanted individually into $10-\mathrm{cm}$-diameter pots filled with a $1: 1$ peat moss/ perlite mix (Sun Grow Horticulture Inc., Bellevue, WA) 10 days after seeding. Plants were fertilized at the four-leaf stage with MiracleGro water-soluble fertilizer $\left(15 \mathrm{~N}, 30 \mathrm{P}_{2} \mathrm{O}_{5}, 15 \mathrm{~K}_{2} \mathrm{O}\right)$. Pots were placed on the greenhouse benches at day and night temperatures of 22 and $18^{\circ} \mathrm{C}$, respectively, with a 16-h photoperiod $\left(250 \mu \mathrm{E} \mathrm{m}^{-2} \mathrm{~s}^{-1}\right)$ until the plants were ready for inoculation.

Inoculum preparation and plant inoculation. Inoculum was prepared from a field isolate (IN95-Lafayette-1196-WW 1-4) of $M$. graminicola that was collected from Lafayette, IN during 1995. The pure culture of the isolate was revived by placing a small ( 1 to $\left.2 \mathrm{~mm}^{2}\right)$ piece of a frozen $\left(-80^{\circ} \mathrm{C}\right)$, lyophilized filterpaper stock onto potato dextrose agar (PDA; $39 \mathrm{~g}$ of potato dextrose agar, 1 liter of water; Difco Laboratories, Detroit) plates exposed to cool, white fluorescent lights under a 12-h photoperiod at 24 to $25^{\circ} \mathrm{C}$. Once the isolate was growing rapidly, inoculum was prepared by placing a $1-\mathrm{cm}^{2}$ piece of agar culture into $250-\mathrm{ml}$ Erlenmeyer flasks containing $100 \mathrm{ml}$ of yeast-sucrose liquid medium (10 $\mathrm{g}$ of sucrose and $10 \mathrm{~g}$ of yeast extract in 1 liter of distilled water) and $100 \mu \mathrm{l}$ of kanamycin sulfate $(25 \mathrm{mg} / \mathrm{ml})$. Flasks were covered with cotton plugs and placed on an orbital shaker (Barnstead/Thermolyne, Dubuque, IA) at $150 \mathrm{rpm}$ for 3 to 5 days. The resulting inoculum suspensions were filtered through two layers of cheesecloth and adjusted to $\approx 4 \times 10^{6}$ spores $/ \mathrm{ml}$ by hemacytometer prior to inoculation. One drop of Tween 20 (polyoxyethylene-sorbitan monolaurate, Sigma-Aldrich, St. Louis) was added per $100 \mathrm{ml}$ of spore suspension.

Plants were inoculated with blastospores of M. graminicola approximately 7 weeks after transplanting, when the flag leaves were fully expanded. Spore suspension $(\approx 20 \mathrm{ml}$ per pot) was sprayed with a hand-operated sprayer. Inoculated plants were covered with polyethylene sheeting lined with canvas and misted with tap water to maintain near $100 \%$ relative humidity. Three days after inoculation, the polyethylene sheeting and canvas were removed and inoculated plants were left uncovered on the greenhouse benches. Greenhouse temperatures ranged from 20 to $28^{\circ} \mathrm{C}$ during the day (mean $24^{\circ} \mathrm{C}$ ) and from 18 to $22^{\circ} \mathrm{C}$ at night (mean $20^{\circ} \mathrm{C}$ ).

Disease assessment and experimental design. Symptoms of STB were assessed from 21 to 28 days after inoculation. Susceptibility and resistance were measured based on the ability of the pathogen to infect and sporulate on the host. Inoculated plants were rated by two disease-assessment methods $(12,15,20,41)$ : (i) disease severity (DS) was based on the visually estimated percentage of leaf area of necrotic lesions containing pycnidia; and (ii) the level of sporulation was estimated as pycnidial density within necrotic lesions ranging from 0 to 5 , where $0=$ no sporulation; $1=$ occasional pycnidia in a few lesions; 2 = a low density of pycnidia in many or most lesions, usually unevenly distributed; 3 = an even distribution of pycnidia at moderate density over most of the lesions; 4 = a high density of pycnidia distributed over most lesions; and $5=$ maximum pycnidial density.

A randomized complete block design was used to test the 130 $\mathrm{F}_{10}$ RILs for resistance to $M$. graminicola during each year. Each pot contained a single plant of a RIL, and each inoculated plant was treated as an experimental unit. From three to six replicate plants of each RIL were inoculated during each experiment, with one experiment performed during the spring and fall of each year. Means of DS and pycnidial density from each year were combined and averaged, and the experimental entries were classified as resistant or susceptible based on the reaction of each RIL across years.

DNA extraction. Young wheat leaves were harvested from the parents and a subset of $114 \mathrm{~F}_{10}$ RILs 14 days after sowing. The leaves were lyophilized for $72 \mathrm{~h}$ and stored at $-80^{\circ} \mathrm{C}$. Genomic DNA was extracted from the two parents and $114 \mathrm{~F}_{10}$ RILs with the Qiagen DNeasy Plant Mini kit according to the specifications of the manufacturer (Qiagen Inc., Valencia, CA). Each DNA sample was adjusted to $25 \mathrm{ng} / \mu \mathrm{l}$ for AFLP and $6 \mathrm{ng} / \mu \mathrm{l}$ for microsatellite marker analysis with a fluorometer (Hoefer Scientific Instruments, San Francisco).

Bulked segregant analysis. Molecular markers putatively linked to the resistance gene were identified by bulked segregant analysis (BSA) (32). Based on greenhouse phenotypic data, bulk DNA samples were assembled by pooling equal amounts of DNA from STB-resistant and STB-susceptible RILs. DNA samples of resistant and susceptible parents and resistant and susceptible bulks were amplified and screened for polymorphisms with AFLP (10 individuals per bulk) and microsatellite (5 individuals per bulk) markers. Once BSA screening identified a specific polymorphism between a resistant and a susceptible bulk, individual cosegregation analysis, based on the associations between marker genotype and STB reaction phenotype, was conducted on the 114 $\mathrm{F}_{10}$ RILs to determine the genetic linkage between the STB resistance gene and a marker.

AFLP marker analysis. AFLP analysis was conducted with the AFLP Analysis System (Invitrogen Life Technologies, Carlsbad, CA) as described by Vos et al. (48). Briefly, $10 \mu \mathrm{l}$ of genomic DNA $(25 \mathrm{ng} / \mu \mathrm{l})$ of each parent and the $114 \mathrm{~F}_{10}$ RILs were digested in a reaction volume of $25 \mu \mathrm{l}$ with $2.5 \mathrm{U}$ each of EcoRI and $\mathrm{MseI}$ restriction enzymes, and ligated to EcoRI and MseI adapters. The digested DNA, together with 2 pmol of EcoRI adapters and 20 pmol of MseI adapters, was ligated with $1 \mathrm{U}$ of T4 ligase. The ligation mix was incubated at $20^{\circ} \mathrm{C}$ for $2 \mathrm{~h}$. The enzyme was inactivated at $70^{\circ} \mathrm{C}$ for $15 \mathrm{~min}$. The ligated product was diluted 10 -fold in TE (10 mM Tris-HCl, pH 8.0, $0.1 \mathrm{mM}$ EDTA). Preamplification was performed in a total volume of $51 \mu \mathrm{l}$ containing $0.2 \mathrm{mM}$ of all four dNTPs (Amersham Pharmacia Biotech, Piscataway, NJ), $1 \mathrm{U}$ of AmpliTaq DNA polymerase (Applied Biosystems, Branchburg, $\mathrm{NJ}), 1 \times$ polymerase chain reaction (PCR) buffer, $1.75 \mathrm{mM} \mathrm{MgCl}_{2}$, $10 \mathrm{ng}$ of ligated DNA fragment, and $60 \mathrm{ng}$ each of EcoRI and MseI primers. The PCR amplification used the following parameters: $94^{\circ} \mathrm{C}$ for $30 \mathrm{~s}, 56^{\circ} \mathrm{C}$ for $1 \mathrm{~min}$, and $72^{\circ} \mathrm{C}$ for $1 \mathrm{~min}$ for 20 cycles, followed by extension at $72^{\circ} \mathrm{C}$ for $5 \mathrm{~min}$. The preamplified PCR products were diluted 1:40 in TE $(\mathrm{pH}$ 8.0) and used as templates for the selective amplification with a combination of two AFLP primers, each containing three or four selective nucleotides at the $3^{\prime}$ end. The sequences of the EcoRI and MseI primers were 5'-GAC TGC GTA CCA ATT C-3' and 5'-GAT GAG TCC TGA GTA A-3', respectively. EcoRI and MseI primers, 
each containing four selective nucleotides at the $3^{\prime}$ end, were synthesized by MWG Biotech, Inc. (Charlotte, NC). Primers used for selective amplification were similar to those described by Vos et al. (48) with the following extensions: AAC, AAG, ACA, ACC, ACG, AGC, AGG, and ACT for EcoRI; and CAA, CAC, CAG, CAT, CTA, CTC, CTG, and CTT, for MseI. The EcoRI primers were labeled with ${ }^{33} \mathrm{P}-\gamma$ ATP (Amersham Pharmacia Biotech) prior to selective amplification and stored at $-20^{\circ} \mathrm{C}$. Selective amplification was carried out in a total volume of $20 \mu \mathrm{l}$ containing $5 \mu \mathrm{l}$ of diluted preamplified product, $0.5 \mu \mathrm{l}$ of labeled EcoRI primer, $50 \mathrm{ng}$ of $\mathrm{Mse}$ I primer, $7.8 \mu \mathrm{l}$ of $10 \times$ PCR buffer, $2 \mu \mathrm{l}$ of sterile distilled water, and 0.2 units of AmpliTaq DNA polymerase. Following PCR, $10 \mu \mathrm{l}$ of formamide dye (containing 98\% formamide, $10 \mathrm{mM}$ EDTA, $0.1 \%$ bromophenol blue, and $0.1 \%$ xylene cyanol) was added to stop the reaction. The samples were denatured at $94^{\circ} \mathrm{C}$ for $5 \mathrm{~min}$ and immediately cooled on ice. All reactions were carried out in a DNA thermal cycler 9600 (PerkinElmer, Norwalk, CT). Each sample (3 to $4 \mu \mathrm{l}$ ) was loaded onto a $6 \%$ denaturing polyacrylamide-sequencing gel (19:1 acrylamide/ Bis) and run in $1 \times$ Tris-borate EDTA electrophoresis buffer at $90 \mathrm{~W}$ for $3 \mathrm{~h}$. A 500-bp DNA ladder (Invitrogen Life Technologies) was used as a size standard. After electrophoresis, the gels were transferred to Whatman 3MM paper (Whatman International, Ltd., Maidstone, England) and dried at $80^{\circ} \mathrm{C}$ for $2 \mathrm{~h}$ on a gel drier (Bio-Rad Laboratories, Hercules, CA). The gels were exposed to X-ray film (Bio-Max MR; Eastman Kodak Co., Rochester, NY) for 2 to 4 days, depending on the signal intensity. The AFLP bands were scored by visual inspection, and AFLP loci were named based on the combination of selective nucleotides in each selective primer (EcoRI and $M s e \mathrm{I})$ and relative size of the band. For example, ACG/CAG5 refers to the fifth polymorphic band (bands numbered from high to low molecular weight) amplified with the primer combination of EcoRI-ACG and MseI-CAG.

Microsatellite marker analysis. A total of 120 microsatellite primer pairs $(38,39)$ selected for maximal coverage of different wheat chromosomes $(1 \mathrm{~A}, 1 \mathrm{~B}, 1 \mathrm{D}, 2 \mathrm{~A}, 2 \mathrm{D}, 3 \mathrm{~A}, 3 \mathrm{~B}, 4 \mathrm{~B}, 5 \mathrm{~B}, 5 \mathrm{D}$, $6 \mathrm{~B}, 7 \mathrm{~A}, 7 \mathrm{~B}$, and 7D) was evaluated for linkage with the STB resistance gene based on polymorphisms between resistant and susceptible parents, contrasting bulks, and $\mathrm{F}_{10}$ RILs. In addition, 20 RFLP primer pairs specific for chromosomes 7B and 7D (33) were tested with BSA (32). Wheat microsatellite loci were designated as either Xgwm (Gatersleben, Germany wheat microsatellite) followed by a locus number according to Röder et al. (39), or $\mathrm{Xgdm}$ (for Gatersleben D-genome microsatellite) according to Pestsova et al. (38). All primers were synthesized by MWG Biotech, Inc.

Microsatellite PCR reactions were performed according to the Hotstar Taqman kit and instructions provided by Qiagen (Qiagen Inc, Valencia, CA). Each PCR reaction $(25 \mu \mathrm{l})$ contained $5.8 \mu \mathrm{l}$ of sterile deionized water, $4 \mu \mathrm{l}$ of Q-solution $(10 \times), 2 \mu \mathrm{l}$ of PCR buffer (10×), $1 \mu \mathrm{l}$ of $\mathrm{MgCl}_{2}(25 \mathrm{mM}), 2 \mu \mathrm{l}$ of dNTPs $(10 \mathrm{mM})$, $2 \mu \mathrm{l}$ of each primer $(4 \mu \mathrm{M}), 0.2 \mu \mathrm{l}$ of Taq DNA polymerase ( 5 units/ $\mu \mathrm{l}$ ), and $6 \mu \mathrm{l}$ of template DNA at $6 \mathrm{ng} / \mu \mathrm{l}$. PCR reactions were accomplished in an MJ Research PTC-100 thermal cycler (MJ Research, Watertown, MA) at standard amplifications of $94^{\circ} \mathrm{C}$ for $3 \mathrm{~min}$, followed by 35 cycles of $44^{\circ} \mathrm{C}$ for $1 \mathrm{~min}$; 50, 55, or $60^{\circ} \mathrm{C}$ (based on primer annealing temperature) for $1 \mathrm{~min}$; and $72^{\circ} \mathrm{C}$ for $2 \mathrm{~min}$; with a final extension at $72^{\circ} \mathrm{C}$ for $7 \mathrm{~min}$ before cooling at $4^{\circ} \mathrm{C}$. PCR products were separated by electrophoresis in $3 \%$ agarose gels (Amresco, Solon, $\mathrm{OH}$ ) at $4 \mathrm{~V} / \mathrm{cm}$ in $0.5 \times$ TAE buffer (0.04 M Tris-acetate and $0.001 \mathrm{M}$ EDTA). Gels were stained with ethidium bromide $(10 \mathrm{mg} / \mathrm{ml})$. DNA banding patterns were visualized with UV light and gel pictures were taken with an electronic photo imaging system (Fotodyne Inc., Hartland, WI).

To further analyze the DNA fragments amplified by microsatellite primers, PCR products were separated on 12\% (29:1 acrylamide/Bis) nondenaturing polyacrylamide gels (398 by 338 by $0.4 \mathrm{~mm}$ ) as described by the manufacturer (Promega Corp.,
Madison, WI). After polymerization, the gel was prerun at $60 \mathrm{~W}$ for $30 \mathrm{~min}$ in $1 \times$ TBE buffer $(0.09 \mathrm{M}$ Tris-borate and $0.002 \mathrm{M}$ EDTA). Gel debris from the wells was removed with a $10-\mathrm{ml}$ plastic syringe and a 49 -well shark-tooth comb (0.4 mm thick) was inserted into the gel. Formamide dye $(5 \mu \mathrm{l})$, as described above, was added to each DNA sample. In all, 6 to $8 \mu \mathrm{l}$ of each sample were loaded onto the gel, which was run at $60 \mathrm{~W}$ for $2 \mathrm{~h}$. Band sizes were estimated relative to a 25-bp DNA ladder standard (Invitrogen Life Technologies). After electrophoresis, PCR products were detected by modification of a silver-staining protocol provided by Kazuhiro Suenaga (Centro Internacional de Mejoramiento de Maíz y Trigo). All steps were carried out on an orbital shaker at $100 \mathrm{rpm}$ (Barnstead/Thermolyne, Dubuque, IA). Briefly, the gel was fixed in acidified ethanol $(100 \mathrm{ml}$ of absolute ethanol and $5 \mathrm{ml}$ of glacial acetic acid per liter) for $5 \mathrm{~min}$ and stained in silver nitrate at $2 \mathrm{~g} /$ liter (Promega Corp.) for $10 \mathrm{~min}$. The gel was rinsed gently with distilled water for $10 \mathrm{~s}$ and DNA bands were developed by soaking for 5 to $15 \mathrm{~min}$ in $\mathrm{NaOH}$ formaldehyde solution ( $10 \mathrm{~g}$ of $\mathrm{NaOH}$ and $5 \mathrm{ml}$ of $37 \%$ formaldehyde per liter). The reaction was stopped by washing in acidified ethanol. The gel was dried overnight and photographs were taken with a Polaroid camera (Fotodyne Inc., Hartland, WI).

Aneuploid analysis. Genomic DNA from normal euploid 'Chinese Spring' (CS) wheat, six nullisomic-tetrasomic (NT) lines of CS stocks for chromosome group 7 (N7AT7B, N7AT7D, N7BT7D, N7BT7A, N7DT7A, and N7DT7B), and the resistant and susceptible parents was amplified by PCR using the specific microsatellite primers for loci Xgwm146, Xgwm577, and Xgwm611. The location of nonpolymorphic loci was determined as described previously (40).

Linkage analysis. Chi-square values were used to test the hypothesis of segregation of resistance versus susceptibility or presence and absence of AFLP or microsatellite markers for the 1:1 ratio expected for a single major gene or molecular marker. Goodness-of-fit values were calculated for all segregation ratios and $P<0.05$ was selected as the level for rejecting the null hypothesis.

A single gene controlling resistance to $M$. graminicola was mapped by linkage analysis with 67 AFLP and 3 microsatellite markers (Xgwm146, Xgwm577, and Xgwm611) that showed polymorphisms between the two parents, contrasting bulks, and 114 $\mathrm{F}_{10}$ RILs. Linkage relationships between the STB resistance gene and AFLP and microsatellite markers were calculated with the MAPMAKER program (25). The Kosambi (23) mapping function was used to convert recombination data into centimorgans (cM). The most probable marker order was obtained by a multipoint analysis. The linkage map was obtained by selecting 0.4 as the maximum recombination fraction and 3.0 as the minimum logarithm of the odds (LOD) ratio.

\section{RESULTS}

Resistance of the mapping population to $M$. graminicola. In the greenhouse, inoculated plants that produced DS (based on percent leaf area infected) of $<5 \%$ with pycnidial density of 0 to 1 were considered resistant, whereas those that produced DS of $>5 \%$ and pycnidial density $>1$ were considered susceptible. Most resistant RILs produced tiny necrotic flecks with DS of $<5 \%$ and no pycnidial formation in response to inoculation with Indiana tester isolate IN95-Lafayette-1196-WW 1-4 of M. graminicola. All susceptible RILs had a high DS ranging from 5 to $40 \%$ with characteristic chlorotic blotches. The large chlorotic lesions of the susceptible RILs usually contained a high density of pycnidia.

Segregation patterns of the resistance to M. graminicola in the mapping population. Both DS (Fig. 1A) and pycnidial density (Fig. 1B) in the mapping population showed a skewed distribution, with the highest number of RILs in the most resistant class. There was no evidence of transgressive segregation, and the 
resistant and susceptible RILs were distinct. Using the criteria of $>5 \%$ DS with sporulation $>1$, the numbers of resistant and susceptible lines in the mapping population were 66 and 64, respectively. This segregation ratio was not significantly different from $1: 1\left(\chi^{2}=0.03 ; P=0.79\right)$, as expected if a single gene conditions the resistance to $M$. graminicola in the synthetic hexaploid wheat W7984.

Molecular mapping of the major gene conferring resistance to $M$. graminicola. Among the 64 AFLP primer combinations tested in the bulked-segregant analysis experiments, 24 revealed polymorphisms between the two parents and contrasting bulks. Each primer combination amplified from 108 to 188 DNA bands. An average of 2 to 11 bands were polymorphic between the two parents and the bulks. Application of the 24 selected AFLP primer combinations resulted in 67 AFLP fragments that were potentially linked to the resistance gene. All of these markers were used to evaluate the same $114 \mathrm{~F}_{10}$ RILs used for previous linkage analyses (33-35). The most probable order of these markers was obtained by multipoint analysis. Only two AFLP markers, EcoRI-ACG/ MseI-CAG2 and EcoRI-ACG/MseI-CAG5, were in the same linkage group as the resistance gene and segregated in a simple Mendelian fashion. The observed segregation ratios of presence
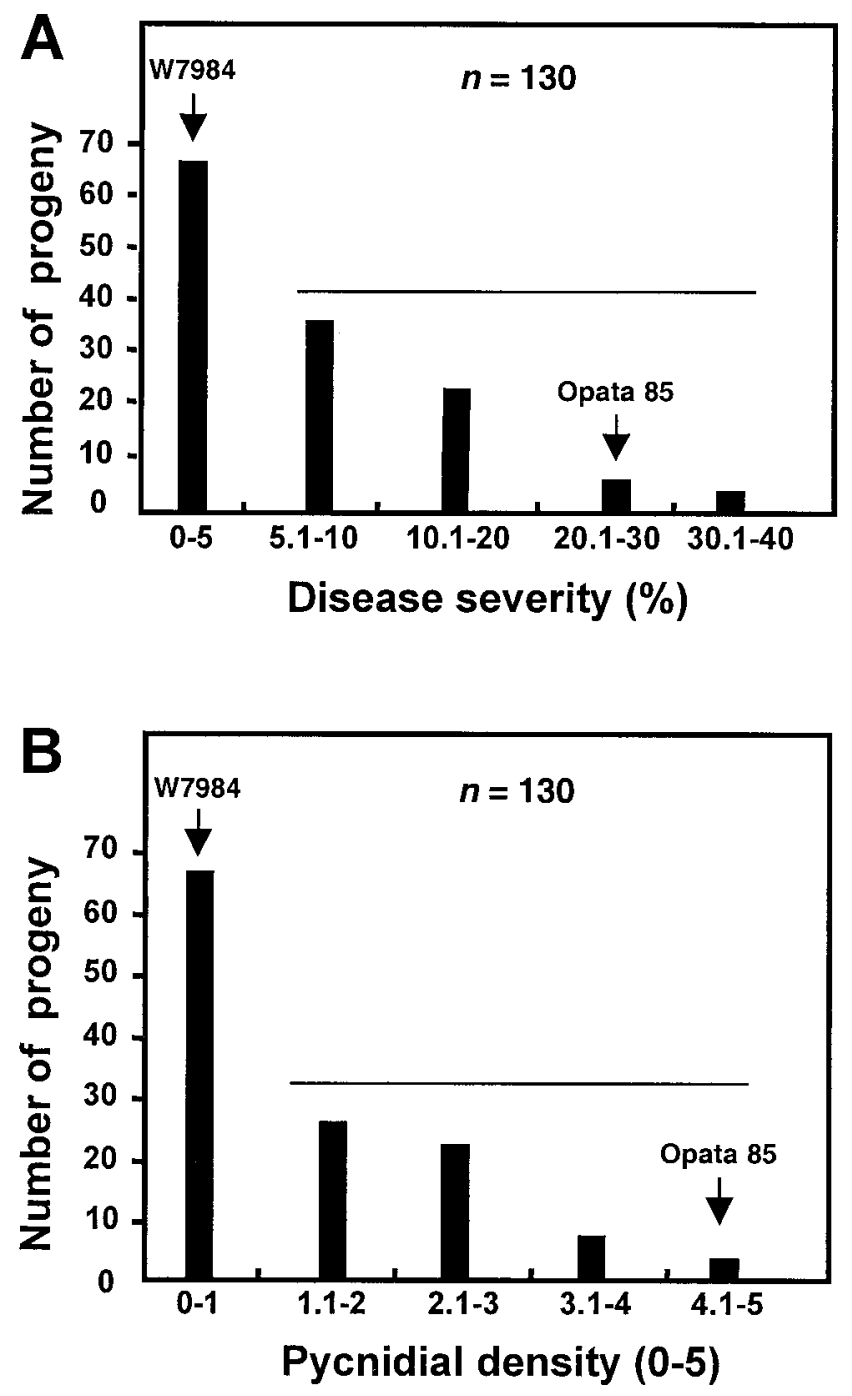

Fig. 1. Segregation of resistance to Mycosphaerella graminicola in the progeny of the cross between the synthetic hexaploid wheat W7984 and Mexican cv. Opata 85. Histograms show the frequency distribution of $\mathbf{A}$, Septoria tritici leaf blotch disease severity $(\%)$ and $\mathbf{B}$, pycnidial density on the $130 \mathrm{~F}_{10}$ recombinant-inbred lines. The disease scores of the parents are indicated by arrows; classes considered susceptible are indicated by horizontal lines. and absence of these two AFLP markers in the $114 \mathrm{~F}_{10}$ RILs were not significantly different from 1:1 (Table 1). Other AFLP markers did not show normal segregation. The closest association found was between EcoRI-ACG/MseI-CAG5 and the gene. This marker was linked in repulsion phase with the resistance gene at a distance of approximately $5.3 \mathrm{cM}$.

Among the 120 microsatellite primers screened for polymorphism between the two parents and the bulks, 36 potentially useful primers were identified. However, when these 36 primer pairs were used to further characterize the individual progeny comprising the bulks, only three, Xgwm146, Xgwm577, and Xgwm611, amplified bands that were consistently polymorphic between the resistant and susceptible progeny arrays. The primer pair Xgwm146 amplified a 200-bp DNA band specific to the resistant wheat cv. W7984, and a 175-bp band from DNA of the susceptible parent Opata 85 (Fig. 2). Linkage analysis indicated that locus $\mathrm{Xgwm} 146$ was linked to the gene at a distance of $3.5 \mathrm{cM}$. On polyacrylamide gels, the primer pair Xgwm577 amplified two products (of $\approx 200$ and $160 \mathrm{bp}$ ) in the resistant wheat parent W7984 and bands of $\approx 180$ and $140 \mathrm{bp}$ in the susceptible parent Opata 85 (Fig. 3). Linkage analysis of the $114 \mathrm{~F}_{10}$ RILs indicated that the Xgwm577 locus was linked to the gene at a distance of $5.3 \mathrm{cM}$. Similarly, the primer pair Xgwm611 amplified a band of $\approx 150 \mathrm{bp}$ in W7984 and a 200-bp band in Opata 85. This marker was linked to the resistance gene at a distance of $19.3 \mathrm{cM}$. Chi-square analysis revealed that the ratios of presence to absence of all three linked markers Xgwm146, Xgwm577, and Xgwm611 were not significantly different from 1:1 (Table 1). In addition, all three microsatellite markers did not amplify DNA from the two NT lines N7BT7D and N7BT7A, confirming their location on chromosome 7B. Multipoint analysis revealed that microsatellites Xgwm 146 and Xgwm577 flanked the resistance locus and that the AFLP locus EcoRI-ACG/MseI-CAG5 was proximal to Xgwm146 on the long arm of chromosome 7B (Fig. 4).

TABLE 1. Chi-square values for amplified fragment length polymorphism (AFLP) and microsatellite markers segregating in a subset of $114 \mathrm{~F}_{10}$ recombinant recombinant-inbred lines (RILs)

\begin{tabular}{llllllll}
\hline & \multicolumn{2}{c}{ W7984 } & & \multicolumn{2}{c}{ Opata 85} & \\
\cline { 2 - 3 } Marker $^{\mathrm{a}}$ & Allele $^{\mathrm{b}}$ & Number & & Allele $^{\mathrm{b}}$ & Number & & $\chi^{2}$ \\
\hline E-ACG/M-CAG2 & + & 61 & & - & 53 & $0.56^{\mathrm{c}}$ \\
E-ACG/M-CAG5 & - & 60 & & + & 54 & 0.32 \\
Xgwm146 & 200 & 56 & & 175 & 58 & 0.04 \\
Xgwm577 & 200,160 & 57 & & 180,140 & 57 & 0.00 \\
Xgwm611 & 150 & 55 & & 200 & 59 & 0.14 \\
\hline
\end{tabular}

a AFLP marker names consist of abbreviations of selective nucleotides from the primers EcoRI (left) and MseI (right) separated by a slash; microsatellite markers are indicated by the prefix Xgwm.

${ }^{b}$ Alleles for AFLP markers are indicated as + or - for presence or absence, respectively, of a band at each locus. For microsatellite loci, approximate sizes of bands (in base pairs) produced by each primer combination from each parent are indicated.

Goodness of fit $\left(\chi^{2}\right)$ of the ratios of the different markers in $\mathrm{F}_{10}$ RILs to that expected for a single gene (1:1). Significance limit of $\chi^{2}(P=0.05$, $\mathrm{df}=1)=3.84$

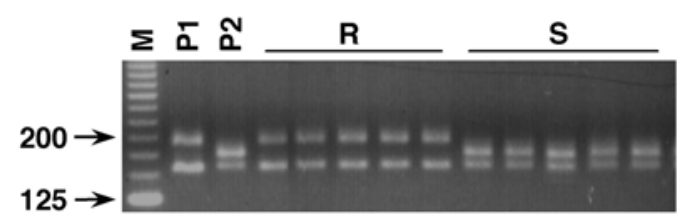

Fig. 2. DNA bands amplified from a subset of $114 \mathrm{~F}_{10}$ recombinant-inbred lines derived from a cross between the synthetic hexaploid wheat W7984 (P1) and Mexican cv. Opata 85 (P2) using the primer pair for microsatellite locus $\mathrm{Xgwm} 146$ in a $3 \%$ agarose gel; $\mathrm{R}=$ resistant, and $\mathrm{S}=$ susceptible. $\mathrm{A}$ 25-bp DNA ladder (M) was used as a standard size marker; sizes of selected bands (in base pairs) are indicated by arrows. 


\section{DISCUSSION}

Resistance to $M$. graminicola in the synthetic hexaploid wheat W7984 is conditioned by a single major gene. Most of the $130 \mathrm{~F}_{10}$ RILs reacted consistently to the Indiana tester isolate of $M$. graminicola over the 4 years of greenhouse inoculations, making the phenotypic scoring and molecular mapping procedures straightforward and precise. However, some RILs gave inconclusive results during one or more testing cycles. These were caused most likely by segregation of genes for maturity, growth habit, or morphology that complicated the testing process in the highly variable progeny of the mapping population. For example, plants in some lines were small and early maturing while others were extremely large and late; therefore, the plants were in different growth stages at the time of inoculation. Plants were segregated by maturity group and inoculated separately during the last 2 years of testing to minimize the effect of growth stage at the time of inoculation on the expression of resistance. Compatible reactions were characterized generally by large lesions containing abundant pycnidia, and incompatibility was characterized by the absence of visible signs or symptoms other than minute flecks, although a few small lesions appeared occasionally on resistant individuals.

The single gene in W7984 is a new STB resistance locus on chromosome 7BL and is designated Stb8. At least seven wheat genes for resistance to $M$. graminicola have been named $(4,6$, 29,46; R. A. McIntosh, personal communication). Among these genes, $S t b 1$, Stb2, and $S t b 3$ were identified using field populations of $M$. graminicola (49) and have not been mapped. However, a resistance gene that is allelic or identical to $S t b 1$ is located on chromosome 5BL (51). A single dominant gene, Stb4, was transferred into the spring wheat cv. Tadinia using a California isolate of $M$. graminicola as a tester (46). The Stb4 gene confers resistance to M. graminicola at both seedling and adult-plant stages. Linkage between Stb4 and molecular markers indicated that this resistance gene is located on wheat chromosome 7D $(2 ;$ T. B. Adhikari and S. B. Goodwin, unpublished data). Gene Stb5 maps to the short arm of wheat chromosome 7D and is linked with microsatellite locus $\mathrm{Xgwm} 44$ at a distance of approximately $7.2 \mathrm{cM}$ (4). More recently, gene Stb6 was mapped to the distal part of the short arm of chromosome $3 \mathrm{~A}$ using microsatellite markers (6). The Stb6 gene also demonstrated isolate specificity to $M$. graminicola and follows a gene-for-gene relationship $(6,14)$. The designation $\mathrm{Stb} 7$ was allocated to a gene on chromosome 4A of cv. Estanzuela Federal (R. A. McIntosh, personal communication). Gene Stb8 on chromosome 7BL clearly must be distinct from the mapped genes $S t b 4, S t b 5, S t b 6$, and $S t b 7$, and probably also from $S t b 1$. The relationships between the $S t b 8$ gene identified in this study and genes Stb2 and Stb3 $(49,50)$ are still unknown. Comparative gene expression analyses of these STB resistances could provide insights into the molecular mechanisms of disease resistance to $M$. graminicola and about the evolution of hostpathogen relationships in this pathosystem.

The linkage map was used to identify the relationship between the molecular markers and Stb8. One AFLP marker, EcoRIACG/MseI-CAG5, was linked in repulsion with $S t b 8$ (i.e., in cou- pling with the susceptible allele) at a distance of $\approx 5.3 \mathrm{cM}$. We also analyzed 20 RFLP markers integrated on wheat chromosomes 7B and 7D. None of the RFLP markers was linked to Stb8. Two flanking microsatellite loci, $X g w m 146$ and $X g w m 577$, were tightly linked to the gene in coupling at distances of 3.5 and $5.3 \mathrm{cM}$, respectively. Availability of the public microsatellite markers greatly facilitated the mapping project. This was expected; microsatellite markers detect higher levels of polymorphism in hexaploid wheat than any other marker system $(7,39,40,47)$.

The chromosomal location of the gene was verified by comparing the DNA bands linked to the STB resistance gene with corresponding bands present or absent in euploids and aneuploids. As expected, the three microsatellite markers Xgwm146, Xgwm577, and Xgwm611 did not amplify DNA bands from the two aneuploid

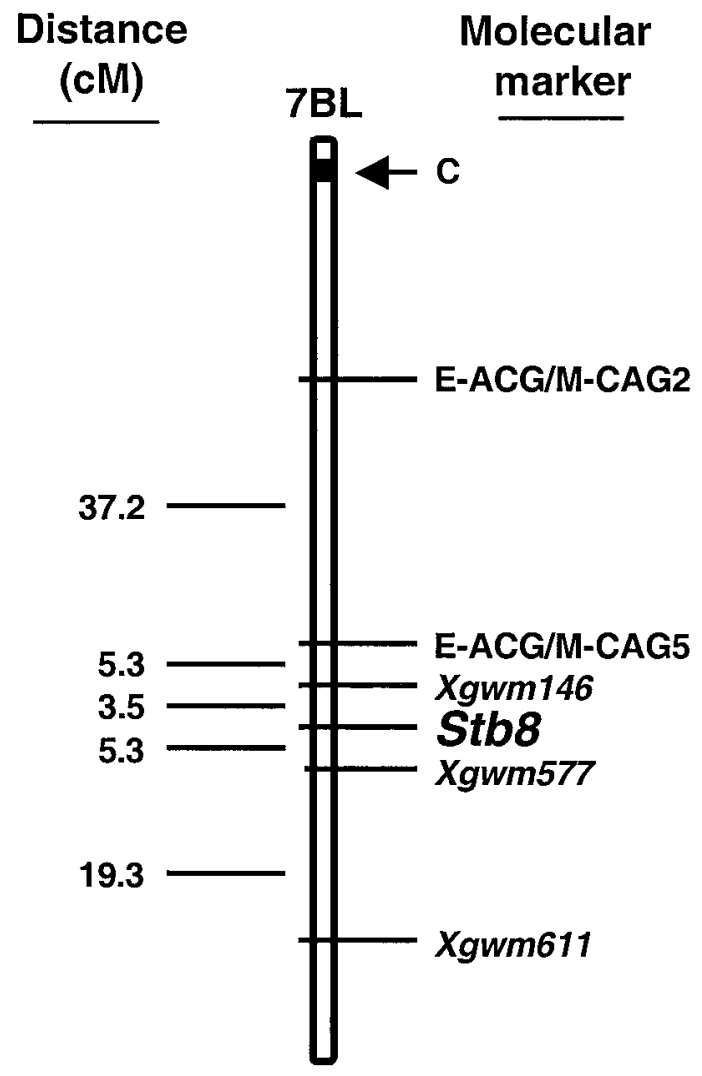

Fig. 4. Linkage map of amplified fragment length polymorphism (AFLP) and microsatellite markers constructed from a subset of $114 \mathrm{~F}_{10}$ recombinantinbred lines derived from a cross between the synthetic hexaploid wheat W7984 and Mexican cv. Opata 85. Distances in centimorgans (cM) are indicated on the left; marker type and resistance locus are shown on the right. The gene $S t b 8$ controls resistance to Mycosphaerella graminicola. An AFLP marker, EcoRI-ACG/MseI-CAG5, was linked in repulsion with the Stb8 gene at a distance of $\approx 5.3 \mathrm{cM}$. The $5 t b 8$ gene was mapped to the long arm of wheat chromosome 7B and was flanked by two microsatellite markers, Xgwm146 and Xgwm577, at distances of 3.5 and $5.3 \mathrm{cM}$, respectively. Letter C denotes the approximate position of the centromere.

$$
F_{10} \text { lines }
$$

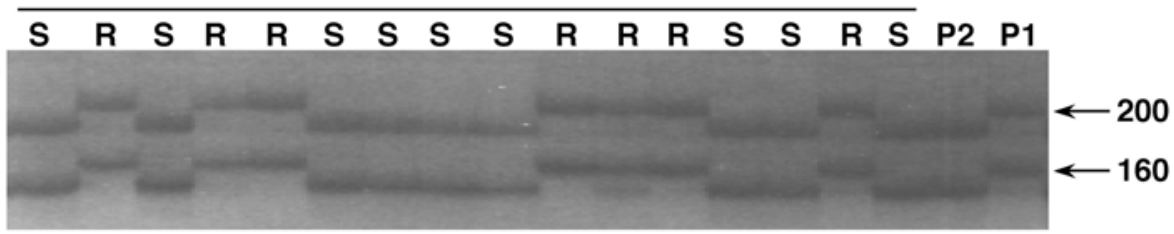

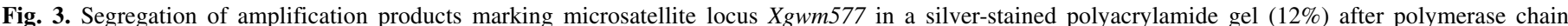

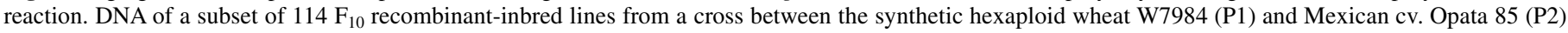

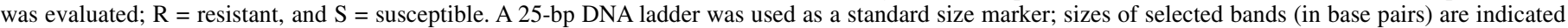
by arrows. 
lines that were nullisomic for chromosome $7 \mathrm{~B}$, confirming that the $S t b 8$ gene is located on this chromosome. The localization of these microsatellite markers to the long arm of chromosome 7B is consistent with the results of Röder et al. (39).

Homoeologous group 7B of the wheat genome seems to play an important role in resistance to several diseases of wheat. Based on intervarietal substitutions, Law and Wolfe (26) identified genes for mildew resistance $(\mathrm{ml})$ and ear emergence time on chromosome 7B. Three linked genes responsible for resistance to stem rust ( $s r 17)$, leaf rust ( $\operatorname{Lr} 14)$, and powdery mildew were located on chromosome 7B of wheat cv. Hope (30). Isozyme markers and genes conferring resistance to eyespot disease and leaf rust also have been mapped independently on wheat chromosome 7B $(22,31)$. So far, no information on the STB gene in the ITMI mapping population has been reported. The synthetic hexaploid wheat W7984 tested in this study originated from a cross between the tetraploid T. turgidum subsp. durum 'Altar 84' (with the A and B genomes) and the diploid progenitor of the D genome of wheat, Aegilops tauschii (syn. T. tauschii). Therefore, the original source for $5 t b 8$ on chromosome $7 \mathrm{~B}$ must have been the durum wheat Altar 84. Previous analyses of pathogenicity variation have revealed a difference between isolates from durum and bread wheat; isolates from bread wheat generally cannot infect accessions of durum wheat and vice versa $(20,21)$. Because $5 t b 8$ must have come from the durum wheat parent of $\mathrm{W} 7984$, it may provide a broad spectrum of resistance against populations of M. graminicola from bread wheat.

The identification of closely linked molecular markers flanking the $5 t b 8$ gene in the synthetic hexaploid wheat W7984 provides the basis for developing a more efficient screen for early-generation breeding populations and transferring this resistance into improved wheat cultivars. Although AFLP marker analysis was able to generate a large number of polymorphic bands in this study, microsatellites were more reliable than AFLPs for generating useful markers. Furthermore, the AFLP marker EcoRI-ACG/MseICAG5 may not be ideal for selection purposes due to the somewhat tedious assay. The flanking microsatellite markers Xgwm146 and Xgwm577 can be used in marker-assisted selection of the Stb8 gene in wheat-breeding programs. Marker-assisted selection-based pyramiding of the Stb8 gene with other STB resistance genes could be a valuable alternative to achieve broader and more durable resistance to $M$. graminicola. For example, pyramiding of different major genes for resistance to Xanthomonas oryzae pv. oryzae has been successfully used in rice to develop broad-spectrum resistance to many races of this pathogen in Asia (18).

In addition to its commercial potential, the $T$. aestivum-M. graminicola pathosystem serves as a model for molecular biology research on wheat. There is a tremendous interest in understanding how resistance genes are involved in response against invading pathogens. Numerous resistance genes have been cloned during the past decade, and a large number of these genes share common nucleotide-binding site (NBS) and leucine-rich repeat (LRR) motifs $(5,13)$. All of these NBS-LRR genes confer resistance by means of a hypersensitive response in which localized cell death triggered in response to pathogen ingress deters the spread of the pathogen. The $S t b 8$ gene, reported here, phenotypically produces a response that appears to lack the rapid cell death characteristic of a classical hypersensitive type of reaction. Thus, it may trigger a different type of resistance response; any progress toward cloning STB resistance genes is a significant step in understanding the gene-for-gene interactions within this pathosystem.

\section{ACKNOWLEDGMENTS}

Published as paper 17081, Purdue University Agricultural Research Programs. This work was supported by USDA-ARS CRIS project 360222000-009-00D. We thank J. Cavaletto, J. Breeden, L. Ayala, D. Bucholtz, B. Wallace, and K. Brikmanis for their excellent technical assistance;
F. Urmeev, B. Roberts, and J. Breeden for performing the greenhouse experiments; $\mathrm{X}$. Hu for the original suggestion to test the parents of the mapping population for resistance; G. Buechley for guidance during the early stages of the disease testing; and H. Ohm, L. Dunkle, and G. Shaner for helpful comments on a previous draft of the manuscript.

\section{LITERATURE CITED}

1. Adhikari, T., Anderson, J. M., and Goodwin, S. B. 2002. Molecular mapping of Septoria tritici leaf blotch resistance in wheat. (Abstr.) Phytopathology 92(suppl.):S2.

2. Adhikari, T., Goodwin, S. B., Dubcovsky, J., and Gieco, J. 2002. An AFLP marker linked to the Stb4 gene for resistance to Septoria tritici leaf blotch in wheat. Page 173 in: Abstr. X Int. Conf. Plant, Animal, and Microbe Genomes, San Diego, CA.

3. Anderson, J. A., Ogihara, Y., Sorrells, M. E., and Tanksley, S. D. 1992. Development of a chromosomal arm map for wheat based on RFLP markers. Theor. Appl. Genet. 83:1035-1043.

4. Arraiano, L. S., Worland, A. J., Ellerbrook, C., and Brown, J. K. M. 2001. Chromosomal location of a gene for resistance to Septoria tritici blotch (Mycosphaerella graminicola) in the hexaploid wheat 'Synthetic 6x'. Theor. Appl. Genet. 103:758-764.

5. Baker, B., Zambriski, P., Staskawicz, B., and Dinesh-Kumar, S. P. 1997. Signaling in plant microbe interactions. Science 276:726-733.

6. Brading, P. A., Verstappen, E. C. P., Kema, G. H. J., and Brown, J. K. M. 2002. A gene-for-gene relationship between wheat and Mycosphaerella graminicola, the Septoria tritici blotch pathogen. Phytopathology 92:439-445.

7. Bryan, G. J., Collins, A. J., Stephenson, P., Orry, A., Smith, J. B., and Gale, M. D. 1997. Isolation and characterization of microsatellites from hexaploid bread wheat. Theor. Appl. Genet. 94:557-563.

8. Camacho-Casas, M. A., Kronstad, W. E., and Scharen, A. L. 1995. Septoria tritici resistance and associations with agronomic traits in a wheat cross. Crop Sci. 35:971-976.

9. Cowger, C., Hoffer, M. E., and Mundt, C. C. 2000. Specific adaptation by Mycosphaerella graminicola to a vertically resistant wheat cultivar. Plant Pathol. 49:445-451.

10. Eyal, Z. 1981. Integrated control of Septoria diseases of wheat. Plant Dis. 65:763-768.

11. Eyal, Z., Prescott, J. M., and van Ginkel, M. 1987. The Septoria Diseases of Wheat: Concepts and Methods of Disease Management. International Maize and Wheat Improvement Centre (CIMMYT), Mexico, D.F.

12. Eyal, Z., Scharen, A. L., Huffman, M. D., and Prescott, J. M. 1985. Global insights into virulence frequencies of Mycosphaerella graminicola. Phytopathology 75:1456-1462.

13. Feuillet, C., Schachermayr, G., and Keller, B. 1997. Molecular cloning of a new receptor-like-kinase gene encoded at the $\operatorname{Lr} 10$ disease resistance locus of wheat. Plant J. 11:45-52.

14. Flor, H. H. 1971. Current status of the gene-for-gene concept. Annu. Rev. Phytopathol. 9:275-296.

15. Gaunt, R. E., Thompson, W. J., and Sutcliffe, J. 1986. The assessment of speckled leaf blotch in winter wheat in New Zealand. Ann. Bot. (Lond.) 58:33-38.

16. Gilbert, J., Woods, S. M., and Tekauz, A. 1998. Relationship between environmental variables and the prevalence, and isolation frequency of leafspotting pathogens in spring wheat. Can. J. Plant Pathol. 20:158-164.

17. Gupta, P. K., Altosaar, I., and Garg, D. K. 1991. Molecular genetics of wheat. Pages 263-289 in: Chromosome Engineering in Plants: Genetics, Breeding, Evolution. Part A. P. K. Gupta and T. Tsuchiya, eds. Elsevier Science Publishers, New York.

18. Huang, N., Angeles, E. R., Domingo, J., Magpantay, G., Singh, S., Zhang, G., Kumaravadivel, N., Bennett, J., and Khush, G. S. 1997. Pyramiding of bacterial blight resistance genes in rice: Marker-assisted selection using RFLP and PCR. Theor. Appl. Genet. 95:313-320.

19. Jackson, L. F., Dubcovsky, J., Gallagher, L. W., Wennig, R. L., Heaton, J., Vogt, H., Gibbs, L. K., Kirby, D., Canevari, M., Carlson, H., Kearney, T., Marsh, B., Munier, D., Mutters, C., Orloff, S., Schmierer, J., Vargas, R., Williams, J., and Wright, S. 2000. 2000 Regional barley and common and durum wheat performance tests in California. Agron. Prog. Rep. 272:1-56.

20. Kema, G. H. J., Annone, J. G., Sayoud, R., Van Silfhout, C., Van Ginkel, M., and de Bree, J. 1996. Genetic variation for virulence and resistance in the wheat-Mycosphaerella graminicola pathosystem. I. Interactions between pathogen isolates and host cultivars. Phytopathology 86:200212.

21. Kema, G. H. J., Sayoud, R., Annone, J. G., and Van Silfhout, C. 1996. Genetic variation for virulence and resistance in the wheat-Mycosphaerella graminicola pathosystem. II. Analysis of interactions between pathogen isolates and host cultivars. Phytopathology 86:213-220. 
22. Koebner, R. M. D., Miller, T. E., Snape, J. W., and Law, C. N. 1987. Wheat endopeptidase: Genetic control, polymorphism, intrachromosomal gene location, and alien variation. Genome 30:186-192.

23. Kosambi, D. D. 1944. The estimation of map distances from recombination values. Ann. Eugen. 12:172-175.

24. King, J. E., Cook, R. J., and Melville, S. C. 1983. A review of Septoria diseases of wheat and barley. Ann. Appl. Biol. 103:345-373.

25. Lander, E. S., Green, P., Abrahamson, J., Barlow, A., Daly, M. J., Lincoln, S. E., and Newburg, L. 1987. MAPMAKER: An interactive computer package for constructing primary genetic linkage maps of experimental and natural populations. Genomics 1:178-181.

26. Law, C. N., and Wolfe, M. S. 1966. Location of genetic factors for mildew resistance and ear emergence time on chromosome $7 \mathrm{~B}$ of wheat. Can. J. Genet. Cytol. 8:462-470.

27. Liu, Y. G., Mori, N., and Tsunewaki, K. 1990. Restriction fragment length polymorphism (RFLP) analysis in wheat. I. Genomic DNA library construction and RFLP analysis in common wheat. Jpn. J. Genet. 65:367-380.

28. McCartney, C. A., Brule-Babel, A. L., and Lamari, L. 2002. Inheritance of race-specific resistance to Mycosphaerella graminicola in wheat. Phytopathology 92:138-144.

29. McIntosh, R. A., Hart, G. E., Devos, K. M., Gale, M. D., and Rogers, W. J. 1998. Catalogue of gene symbols of wheat. Page 129 in: Proc. 9th Int. Wheat Genet. Symp. Vol. 5. Univ. Ext. Press. University of Saskatchewan, Saskatoon, Canada.

30. McIntosh, R. A., Luig, N. H., and Baker, E. P. 1967. Genetic and cytogenetic studies of stem rust, leaf rust, and powdery mildew resistances in Hope and related wheat cultivars. Aust. J. Biol. Sci. 20:11811192.

31. McMillin, D. E., Allan, R. E., and Roberts, D. E. 1986. Association of an isozyme locus and strawbreaker foot rot resistance derived from Aegilops ventricosa in wheat. Theor. Appl. Genet. 72:743-747.

32. Michelmore, R. W., Paran, I., and Kesseli, R. V. 1991. Identification of markers linked to disease resistance genes by bulked segregant analysis: A rapid method to detect markers in specific genomic regions by using segregating populations. Proc. Natl. Acad. Sci. USA. 88:98289832.

33. Nelson, J. C., Sorrells, M. E., Van Deynze, A. E., Lu, Y. H., Atkinson, M., Bernard, M., Leroy, P., Faris, J. D., and Anderson, J. A. 1995. Molecular mapping of wheat: Major genes and rearrangement in homoeologous groups 4, 5, and 7. Genetics 141:721-731.

34. Nelson, J. C., Van Deynze, A. E., Autrique, E., Sorrells, M. E., Lu, Y. H., Negre, S., Bernard, M., and Leroy, P. 1995. Molecular mapping of wheat: Homoeologous group 2. Genome 38:516-524.

35. Nelson, J. C., Van Deynze, A. E., Autrique, E., Sorrells, M. E., Lu, Y. H., Negre, S., Bernard, M., and Leroy, P. 1995. Molecular mapping of wheat: Homoeologous group 3. Genome 38:525-533.
36. Patterson, F. L., Roberts, J. J., Finney, R. E., Shaner, G. E., Gallun, R. L., and Ohm, H. W. 1975. Registration of Oasis wheat. Crop Sci. 15:736-737.

37. Patterson, F. L., Shaner, G. E., Huber, D. M., Ohm, H. W., Finney, R. E., Gallun, R. L., and Roberts, J. J. 1979. Registration of Sullivan wheat. Crop Sci. 19:297.

38. Pestsova, E., Ganal, M. W., and Röder, M. S. 2000. Isolation and mapping of microsatellite markers specific for the D genome of bread wheat. Genome 43:689-697.

39. Röder, M. S., Korzun, V., Wendehake, K., Plaschke, J., Tixier, M-H., Leroy, P., and Ganal, M. W. 1998. A microsatellite map of wheat. Genetics 149:2007-2023.

40. Röder, M. S., Plaschke, J., Konig, S., Borner, A., Sorrells, M. E., Tanksley, S. D., and Ganal, M. W. 1995. Abundance, variability and chromosomal location of microsatellites in wheat. Mol. Gen. Genet. 246:327-333.

41. Rosielle, A. A. 1972. Sources of resistance in wheat to speckled leaf blotch caused by Septoria tritici. Euphytica 21:152-161.

42. Rosielle, A. A., and Brown, A. G. P. 1979. Inheritance, heritability, and breeding behavior of three sources of resistance to Septoria tritici in wheat. Euphytica 28:385-392.

43. Shaner, G., and Finney, R. E. 1976. Weather and epidemics of Septoria leaf blotch of wheat. Phytopathology 66:781-785.

44. Shaner, G., and Finney, R. E. 1982. Resistance in soft red winter wheat to Mycosphaerella graminicola. Phytopathology 72:154-158.

45. Shipton, W. A., Boyd, W. R. L., Rosielle, A. A., and Shearer, B. L. 1971. The common Septoria diseases of wheat. Bot. Rev. 37:231-262.

46. Somasco, O. A., Qualset, C. O., and Gilchrist, D. G. 1996. Single-gene resistance to Septoria tritici blotch in the spring wheat cultivar 'Tadinia'. Plant Breed. 115:261-267.

47. Stephenson, P., Bryan, G., Kirby, J., Collins, A., Devos, K., Busso, C., and Gale., M. D. 1998. Fifty new microsatellite loci for the wheat genetic map. Theor. Appl. Genet. 97:946-949.

48. Vos, P., Hogers, R., Bleeker, M., Reijans, M., van der Lee, T., Hornes, M., Frijters, A., Pot, J., Peleman, J., Kuiper, M., and Zabeau, M. 1995. AFLP: A new technique for DNA fingerprinting. Nucleic Acids Res. 23:4407-4414.

49. Wilson, R. E. 1979. Resistance to Septoria tritici in two wheat cultivars determined by independent single dominant genes. Australas. Plant Pathol. 8:16-18.

50. Wilson, R. E. 1985. Inheritance of resistance to Septoria tritici in wheat. Pages 33-35 in: Septoria of Cereals: Proc. Workshop. A. L. Scharen, ed. Montana State University, Bozeman.

51. Yang, X. 2000. Genetic analysis and development of molecular markers for a resistance locus to Mycosphaerella graminicola in wheat. Ph.D. thesis. Purdue University, West Lafayette, IN.

52. Zhang, X., Haley, S. D., and Jin, Y. 2001. Inheritance of Septoria tritici blotch resistance in winter wheat. Crop Sci. 41:323-326. 